\title{
Analisis Kepatuhan Wajib Pajak Orang Pribadi Dalam Penerapan Sistem E-Filling Dengan Pemahaman Internet Sebagai Variabel Pemoderasi Di Rumah Sakit Umum Daerah Kabupaten Jombang
}

\author{
Suluh Agus Hendrawan, Sugeng Suprapto \\ STIE PGRI Dewantara Jombang
}

Korespondensi: sa.hendrawan@gmail.com

abstrak

Penelitian ini bertujuan adalah untuk mengetahui Pemahaman Internet dapat memoderasi hubungan antara Penerapan Sistem E-Filling dengan Kepatuhan Wajib Pajak di Rumah Sakit Umum Daerah Kabupaten Jombang. Penelitian ini termasuk penelitian deskriptif kuantitatif. Hasil penelitian menunjukkan bahwa Penerapan Sistem E-Filling berpengaruh terhadap Kepatuhan Wajib Pajak di Rumah Sakit Umum Daerah Kabupaten Jombang dan Pemahaman Internet memoderasi pengaruh Penerapan Sistem E-Filling terhadap Kepatuhan Wajib Pajak di Rumah Sakit Umum Daerah Kabupaten Jombang, dalam penelitian ini direktorat Jenderal Pajak diharapkan mensosialisasikan tata cara penggunaan e-filing lewat iklan di kantor pajak terutama untuk pemula dan Direktorat Jenderal Pajak sebaiknya lebih menyederhanakan sistem e-filing karena banyak Wajib Pajak yang merasa kesuliatan dalam menggunakan e-filing

Kata Kunci : kepatuhan wajib pajak orang pribadi, sistem e-filling, pemahaman internet

\section{abstract}

This study aims to determine the understanding of the Internet can moderate the relationship between the application of E-Filling System with Taxpayer Compliance in the Regional General Hospital of Jombang Regency. This research includes quantitative descriptive research. The results showed that the application of EFilling System had an effect on the compliance of taxpayers in the Regional General Hospital of Jombang Regency and the understanding of the Internet moderated the effect of the application of E-Filling System on taxpayer compliance at the Jombang District Regional General Hospital. socializing the procedures for using e-filing through advertisements in the tax office, especially for beginners and the Directorate General of Taxation should better simplify the e-filing system because many taxpayers feel that they are eager to use e-filing

Keywords: personal taxpayer compliance, e-filling system, and internet understanding.

\section{A. LATAR BELAKANG}

Pajak merupakan tulang punggung penerimaan negara dan digunakan untuk membiayai pengeluaran negara. Pajak berasal dari iuran masyarakat dan dapat dipaksakan dengan tidak mendapat imbalan secara langsung yang dikelola oleh Direktorat Jenderal Pajak. Menurut Berly Angkoso (2010), Secara keseluruhan Pemerintah menargetkan penerimaan perpajakan sebesar Rp1.825,5 triliun. Target pendapatan Negara tesebut bersumber dari Penerimaan Perpajakan ( pajak ditambah bea dan cukai ) sebesar Rp 1.546,7 triliun dan dan baru tercapai sebesar Rp 406,9 triliun pada mei ini. Sedangkan Target Penerimaan Negara bukan pajak baru tercapai Rp 273,8 triliun. "lifting (produksi minyak) menurun dan tidak mencapai target. Tahun ini masih terdapat 42 juta wajib pajak yang belum terjangkau "(www.pajak.go.id). 
Oleh karena itu, untuk meningkatkan kepatuhan Wajib Pajak, Direktorat Jenderal Pajak selalu berupaya mengoptimalkan pelayanan sehingga diharapkan dapat meningkatkan kesadaran dan keinginan masyarakat untuk tertib sebagai Wajib Pajak, salah satunya dengan melakukan reformasi perpajakan. Gunadi dalam Feri Kristianto (2014). menyatakan bahwa reformasi perpajakan meliputi dua area, yaitu reformasi kebijakan pajak berupa regulasi atau peraturan perpajakan seperti undang-undang perpajakan dan reformasi administrasi perpajakan. Reformasi administrasi perpajakan memiliki beberapa tujuan. Pertama, memberikan pelayanan kepada masyarakat dalam memenuhi kewajiban perpajakannya. Kedua, mengadministrasikan penerimaan pajak sehingga transparansi dan akuntabilitas penerimaan sekaligus pengeluaran pembayaran dana dari pajak setiap saat dapat diketahui. Ketiga, memberikan suatu pengawasan terhadap pelaksanaan pemungutan pajak, terutama adalah kepada aparat pengumpul pajak, kepada Wajib Pajak, ataupun kepada masyarakat pembayar pajak. Agar tujuan tersebut tercapai, program reformasi administrasi perpajakan perlu dirancang dan dilaksanakan secara menyeluruh dan komprehensif melalui perubahan- perubahan dalam bidang struktur organisasi, proses bisnis dan teknologi informasi dan komunikasi, manajemen sumber daya manusia, dan pelaksanaan good governance (Sari, 2013).

Menjawab dan menyikapi meningkatnya kebutuhan komunitas Wajib Pajak yang tersebar di seluruh Indonesia akan tingkat pelayanan yang harus semakin baik, membengkaknya biaya pemrosesan laporan pajak, dan keinginan untuk mengurangi beban proses administrasi laporan pajak menggunakan kertas, maka Direktur Jenderal Pajak mengeluarkan Keputusan Direktur Jenderal Pajak Nomor KEP-88/PJ./2004 tanggal 14 Mei 2004 (BN No. 7069 hal. 4B) tentang Penyampaian Surat Pemberitahuan secara Elektronik (Novarina, 2005). Pada tanggal 24 Januari 2005 bertempat di Kantor Kepresidenan, Presiden Republik Indonesia bersama-sama dengan Direktorat Jenderal Pajak meluncurkan produk E-Filling atau Electronic Filing System yaitu sistem pelaporan/penyampaian pajak dengan Surat Pemberitahuan (SPT) secara elektronik (E-Filling) yang dilakukan melalui sistem on-line yang real time. Hal ini layak dilakukan, mengingat, masyarakat Indonesia yang saat ini tengah memasuki era revolusi industry 4.0, juga semakin dekat dan terbiasa dengan pemakaian teknologi berbasis internet (Mutiarni, R. 2017)

Dalam Keputusan Direktur Jenderal Pajak tersebut dinyatakan bahwa Penyampaian Surat Pemberitahuan secara elektonik (E-SPT) dilakukan melalui Perusahaan Penyedia Jasa Aplikasi (Application Service Provider) yang ditunjuk oleh Direktur Jenderal Pajak (Novarina, 2005). Untuk pengaturannya lebih lanjut maka dikeluarkan Peraturan Direktur Jenderal Pajak Nomor KEP05/PJ./2005tanggal 12 Januari 2005 tentang Tata Cara Penyampaian Surat Pemberitahuan secara Elektronik (E-Filling) melalui Perusahaan Penyedia Jasa Aplikasi (ASP). Namun dalam praktiknya, sistem ini bukan merupakan hal yang mudah untuk dilaksanakan. Hal tersebut dikarenakan sistem ini masih baru sehingga masih terdapat kekurangan-kekurangan dan masih banyak hal-hal yang harus dipahami yang terkait dengan kesiapan sumber daya manusia, sarana serta 
perangkatnya sehingga butuh proses dan waktu panjang, disamping harus mengikuti perkembangan Teknologi Informatika (Novarina, 2005).

Penelitian Sari Nurhidayah (2015) dengan judul Pengaruh Teknologi Informasi (e-sistem) terhadap kepatuhan wajib pajak (studi kasus dikantor pelayanan pajak pratama mojokerto) dengan hasil penelitian sistem yaitu E-REG, E-SPT, E-Filling dan E-NPWP tidak berpengaruh signifikan secara statistik terhadap kepatuhan waib pajak di KPP Pratama mojokerto dan hasil uji statistik menunjukan bahwa $E-R E G$ merupakan variabel yang mpunyai nilai koefisien yang tebesar dibandingkan variabel lainya. Dalam penelitian juga ini ditemukan bahwa masih banyak wajib pajak yang belum begitu memahami manfaat e-sistem.

\section{B. KAJIAN PUSTAKA}

\section{Pengertian Pajak}

Terdapat bermacam-macam pengertian atau definisi pajak, namun pada hakekatnya maksud dan tujuan dari pajak itu seragam. Menurut pasal 1 UndangUndang Nomor 16 tahun 2009 tentang KUP berbunyi:

"Pajak adalah kontribusi wajib kepada negara yang terutang oleh orang pribadi atau badan yang bersifat memaksa berdasarkan Undang-Undang, dengan tidak mendapat imbalan secara langsung dan digunakan untuk keperluan negara bagi sebesar-besarnya kemakmuran rakyat."

Kemudian menurut Soemahamidjaja, S dalam Utomo (2015) pajak merupakan iuran yang bersifat wajib, berupa uang atau barang, yang dipungut oleh pemerintah berdasarkan norma-norma hukum, yang digunakan untuk menutupi biaya produksi barang-barang dan jasa-jasa kolektif untuk mencapai kesejahteraan umum, sedangkan menurut Prof. Dr. Andriani dalam Yuniar Rachdianti. (2011) pajak adalah iuran dari masyarakat kepada negara yang dapat dipaksakan dan terutang oleh pihak yang wajib membayarnya berdasarkan peraturan perundang-undangan dengan tidak mendapat prestasi kembali secara uang atau barang kepada negara yang terutang oleh Orang Pribadi atau Badan yang dapat dipaksakan sesuai peraturan perundang-undangan dengan tidak mendapat imbalan secara langsung yang digunakan untuk membiayai keperluan negara dalam menyelenggarakan pemerintahan untuk mencapai kesejahteraan umum.

\section{Kepatuhan Wajib Pajak}

Menurut Yuniar Rachdianti (2011) kepatuhan perpajakan dapat didefinisikan sebagai keadaan dimana Wajib Pajak memenuhi semua kewajiban perpajakan dan melaksanakan hak perpajakannya, sedangkan menurut Nasucha (2004) dalam Utomo (2015) Kepatuhan Wajib Pajak dapat diidentifikasi dari Kepatuhan Wajib Pajak dalam mendaftarkan diri, kepatuhan untuk menyetorkan kembali Surat Pemberitahuan, kepatuhan dalam penghitungan dan pembayaran pajak terutang dan kepatuhan dalam pembayaran tunggakan. Jadi, Kepatuhan Wajib Pajak adalah ketika Wajib Pajak memenuhi semua kewajiban perpajakan dan melaksanakan hak perpajakannya, kewajiban perpajakan meliputi mendaftarkan diri, menghitung dan membayar pajak terutang, membayar tunggakan dan menyetorkan kembali surat pemberitahuan.

\section{Pengaruh Penerapan Sistem E-Filling terhadap Kepatuhan Wajib Pajak}


Pajak merupakan sumber utama penerimaan negara yang dikelola oleh Direktorat Jenderal Pajak. Untuk dapat memaksimalkan sumber penerimaan negara, dibutuhkan Wajib Pajak yang patuh melaksanakan kewajibannya yaitu membayarkan pajaknya kepada negara. Maka dari itu, Direktorat Jenderal Pajak selalu berupaya mengoptimalkan pelayanannya supaya Wajib Pajak tidak enggan melaksanakan kewajibannya. Salah satu cara mengoptimalkan pelayanan tersebut adalah dengan memperbarui atau menyempurnakan sistem administrasi perpajakan atau biasa dikenal dengan istilah sistem administrasi perpajakan modern yang dilakukan melalui reformasi administrasi perpajakan yang diharapkan dapat memberikan kemudahan dan kenyamanan dalam pelayanannya kepada Wajib Pajak untuk memenuhi kewajiban perpajakannya (Gunadi dalam Yuniar Rachdianti. (2011). E-filling merupakan bagian dari reformasi administrasi perpajakan yang bertujuan untuk memudahkan dalam pembuatan dan penyerahan laporan SPT kepada Direktoran Jenderal Pajak. Dengan diterapan sistem e-filling diharapkan dapat memberikan kenyaman dan kepuasan kepada Wajib Pajak sehingga dapat meningkatkan kepatuhan Wajib Pajak (Ayu, 2005).

\section{Pengaruh Penerapan Sistem E-Filling terhadap Kepatuhan Wajib Pajak dengan Pemahaman Internet sebagai Variabel Pemoderasi.}

E-Filing merupakan program modernisasi yang dirancang untuk memanfaatkan IT secara maksimal. Menurut PER-01/PJ/2014, e-Filing adalah suatu cara penyampaian SPT Tahunan secara elektronik yang dilakukan secara online dan real time melalui internet pada website Direktorat Jenderal Pajak (www.pajak.go.id) atau Penyedia Jasa Aplikasi atau Applicatiom Service Provider (ASP). Sistem e-filling merupakan layanan pengisian dan penyampaian Surat Pemberitahuan Wajib Pajak secara elektronik kepada Direktorat Jenderal Pajak yang bertujuan untuk memberikan kenyamanan dan kemudahan bagi Wajib Pajak dalam penyampaian Surat Pemberitahuannya dengan memanfaatkan jaringan komunikasi internet. Untuk dapat menggunakan system tersebut, Wajib Pajak dituntut untuk mengerti atau paham terhadap internet yaitu mengetahui bagaimana cara mengoperasikan internet. Apabila Wajib Pajak tidak dapat mengoperasikan internet, penerapan sistem tersebut tidak berpengaruh apa-apa terhadap kenyaman dan kemudahan dalam penyampaian SPT kepada kantor pajak yang diharapkan dapat meningkatkan kepatuhan Wajib Pajak. Yuniar Rachdianti. (2011)

\section{Kerangka Konseptual}

Berdasarkan penjelasan kerangka pemikiran yang telah dipaparkan sebelumnya, maka dapat dibuat sebuah rerangka penelitian sebagai berikut;

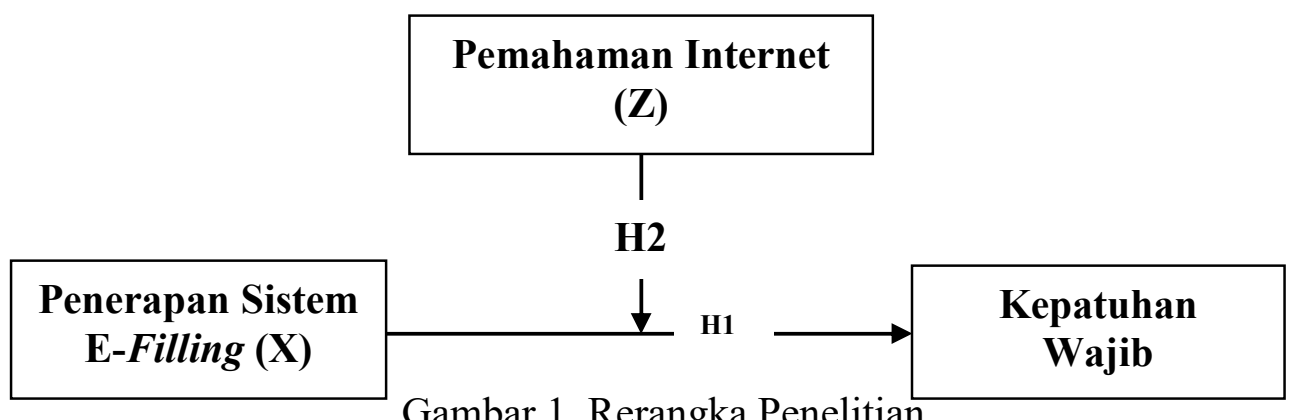


Berdasarkan gambar 1 (satu) diatas maka hipotesis penelitian yang diajukan sebagai jawaban sementara terhadap rumusan masalah penelitian ini adalah sebagai berikut:

H1 : Penerapan Sistem E-Filling berpengaruh terhadap Kepatuhan Wajib Pajak di Rumah Sakit Umum Daerah Kabupaten Jombang

H2 : Pemahaman Internet memoderasi pengaruh Penerapan Sistem EFilling terhadap Kepatuhan Wajib Pajak di Rumah Sakit Umum Daerah Kabupaten Jombang.

\section{METODE PENELITIAN}

Penelitian ini merupakan jenis penelitian yang menggunakan metode penelitian kuantitatif melalui survai. Sumber data yang digunakan dalam penelitian ini adalah data primer. Data primer dalam penelitian ini berupa jawaban atas kuesioner yang dibagikan kepada responden.

Populasi dalam penelitian ini adalah Wajib Pajak Orang Pribadi yang terdaftar sebagai Wajib Pajak E-Filling di Rumah Sakit Umum Daerah Kabupaten Jombang sebanyak 629 Wajib Pajak. Dalam menentukan jumlah sampel dalam penelitian ini menggunakan rumus Slovin, sebagai berikut:

$$
\mathrm{n}=\frac{N}{1+\mathrm{n}_{\mathrm{e}}^{2}}
$$

Instrumen kuisioner untuk variabel Penerapan Sistem E-filling (X) yang digunakan dalam penelitian ini mengacu kepada keuntungan diterapkannya sistem $e$-filling yang digunakan sebagai indikator penelitian. Instrumen ini menggunakan 15 pertanyaan. Skala pengukuran yang digunakan adalah skala likert. Pernyataan yang digunakan merupakan pernyataan positif dengan kriteria sangat tidak setuju, tidak setuju, netral, setuju, dan sangat setuju dengan rentang nilai 1-5.

Instrumen kuisioner untuk variabel Pemahaman Internet $(Z)$ yang digunakan dalam penelitian ini mengacu pada manfaat internet dalam kehidupan sehari-hari yang digunakan sebagai indikator penelitian. Instrumen ini menggunakan 6 pertanyaan. Skala pengukuran yang digunakan untuk mengukur jawaban responden adalah skala likert $1-5$, berupa pernyataan sangat tidak setuju, tidak setuju, netral, setuju, dan sangat setuju.

Untuk Teknik Analisa Data, peneliti menggunakan Moderated Regression Analysis (MRA). Dalam MRA digunakan pendekatan analitik yang mempertahankan integritas sampel dan merupakan dasar untuk mengontrol pengaruh variabel pemoderasi. Berikut ini persamaan regresi untuk menentukan jenis variabel pemoderasi menurut Imam Ghozali (2011)

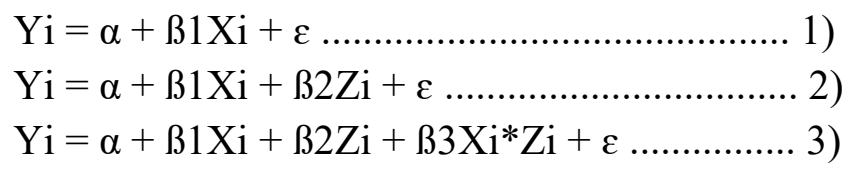

Keterangan :

Yi = Kepatuhan Wajib Pajak 


$$
\begin{aligned}
& \alpha=\text { Bilangan Konstanta } \\
& \beta=\text { Koefisien arah persamaan penelitian } \\
& X=\text { Penerapan sistem e-filling } \\
& Z=\text { jenis variabel moderator } \\
& \varepsilon=\text { Kesalahan pengganggu }
\end{aligned}
$$

Apabila persamaan ke-2 dan ke-3 tidak berbeda secara signifikan maka Z bukanlah variabel moderator, melainkan variabel independen.

\section{HASIL DAN PEMBAHASAN PENELITIAN}

Pengaruh Penerapan Sistem E-Filling berpengaruh terhadap Kepatuhan Wajib Pajak (X terhadap Y)

\section{Tabel 1: Analisa regresi}

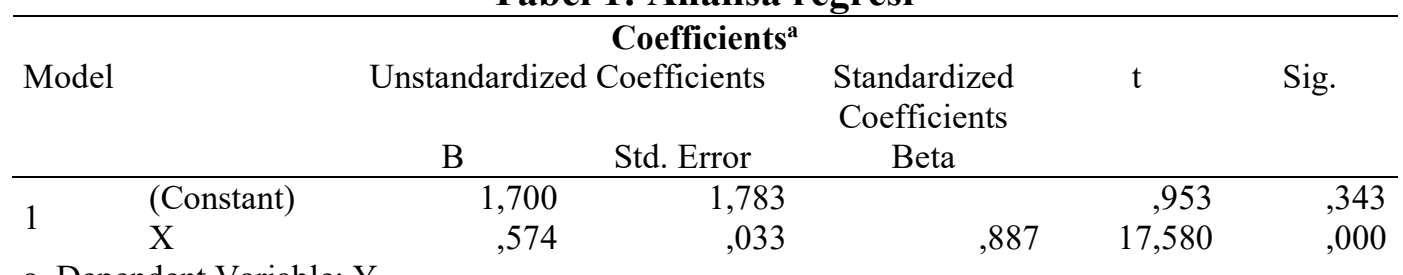

a. Dependent Variable: Y

\section{Sumber: Data primer diolah}

Dari hasil analisis regresi diatas maka persamaan regresinya adalah:

$\mathrm{Y}=1,700+0,574 \mathrm{X}$

Dari model tersebut dapat dikatakan bahwa penerapan Sistem E-Filling mempunyai pengaruh yang positif terhadap Kepatuhan Wajib Pajak. Ini terlihat dari koefisien regresi yang positif. Setiap kenaikan variabel penerapan Sistem $E$ Filling sebesar satu satuan akan meningkatkan Kepatuhan Wajib Pajak sebesar 0.574 satuan. Selanjutnya dilakukan pengujian signifikansi pengaruh Sistem $E$ Filling terhadap Kepatuhan Wajib Pajak dengan hipotesis sebagai berikut:

\section{Pengaruh Penerapan Sistem E-Filling terhadap Kepatuhan Wajib Pajak di Rumah Sakit Umum Daerah Kabupaten Jombang.}

Berdasarkan pengujian sebelumnya dengan menggunakan SPSS diketahui nilai t-hitung untuk variabel Sistem E-Filling adalah sebesar 17,580 Sedangkan nilai t-tabel pada tingkat kepercayaan 95\% dan derajat bebas sebesar n-k-1 = 86$1-1=84$ adalah sebesar 1.988. Karena nilai t-hitung yang diperoleh lebih besar dari nilai t-tabel maka Hipotesis pertama diterima. Dengan demikian dapat disimpulkan terdapat pengaruh yang positif dan signifikan variabel Penerapan Sistem E-Filling terhadap Kepatuhan Wajib Pajak. Semakin baik Penerapan Sistem E-Filling maka Kepatuhan Wajib Pajak akan semakin baik pula. Besar pengaruh Penerapan Sistem E-Filling terhadap Kepatuhan Wajib Pajak dihitung dengan menggunakan koefisien determinasi pada tebel berikut: 
Tabel 2: Model Summary

\begin{tabular}{|c|c|c|c|c|}
\hline Model & $\mathrm{R}$ & R Square & Adjusted R Square & Std. Error of the Estimate \\
\hline 1 & $887^{\mathrm{a}}$ &, 786 & ,784 & 2,557 \\
\hline
\end{tabular}

Sumber: Data Primer diolah

Berdasarkan tabel di atas dapat dijelaskan bahwa diperoleh nilai $\mathrm{R}$ Square sebesar 0,786. Hal ini berarti bahwa variabel Penerapan Sistem E-Filling memiliki kontribusi terhadap Kepatuhan Wajib Pajak sebesar 78,6\% sisanya dipengaruhi variabel lain.

\section{Pengaruh Penerapan Sistem E-Filling terhadap Kepatuhan Wajib Pajak yang dimoderasi Pemahaman Internet.}

Untuk melihat apakah variabel pemahaman internet mampu memperkuat atau memperlemah pengaruh Penerapan Sistem E-Filling terhadap Kepatuhan Wajib Pajak digunakan analisis MRA (Moderating Regression Analysis). Hasil analisis dengan menggunakan SPSS adalah sebagai berikut :

Tabel 3: Pengaruh Penerapan Sistem E-Filling terhadap Kepatuhan Wajib Pajak yang dimoderasi Pemahaman Internet

\begin{tabular}{|c|c|c|c|c|c|c|}
\hline \multicolumn{7}{|c|}{ Coefficients $^{\mathrm{a}}$} \\
\hline \multirow{2}{*}{\multicolumn{2}{|c|}{ Model }} & \multirow{2}{*}{\multicolumn{2}{|c|}{$\begin{array}{l}\text { Unstandardized } \\
\text { Coefficients } \\
\begin{array}{lc}\text { B Std. } \\
\end{array}\end{array}$}} & \multirow{2}{*}{$\begin{array}{l}\text { Standardized } \\
\text { Coefficients } \\
\text { Beta }\end{array}$} & \multirow[t]{2}{*}{$\mathrm{t}$} & \multirow[t]{2}{*}{ Sig. } \\
\hline & & & & & & \\
\hline \multirow{3}{*}{1} & (Constant) &, 402 & 1,547 & & 260 & ,796 \\
\hline & $\mathrm{X}$ & ,313 & 055 & ,483 & 5,730 &, 000 \\
\hline & Z & ,715 &, 128 & 471 & 5,590 &, 000 \\
\hline
\end{tabular}

a. Dependent Variable: Y

Sumber: Data Primer diolah

Dari hasil analisis diatas terlihat bahwa variabel penerapan Sistem E-Filling dan pemahaman internet memiliki koefisien regresi yang positif. Artinya semakin baik Penerapan Sistem E-Filling maka Kepatuhan Wajib Pajak yang dihasilkan akan semakin baik pula. Demikian juga dengan pemahaman internet. Semakin tinggi tingkat pemahaman internet maka Kepatuhan Wajib Pajak juga akan semakin meningkat.

Setelah diperoleh model regresi, selanjutnya dilakukan pengujian model regresi yang diperoleh secara keseluruhan. Hasilnya tampak sebagai berikut

Tabel 4: Pengujian Model MRA

\begin{tabular}{|c|c|c|c|c|c|}
\hline \multicolumn{6}{|c|}{ ANOVA $^{\mathrm{a}}$} \\
\hline Model & & Sum of Squares & $\mathrm{df}$ & $\mathrm{F}$ & Sig. \\
\hline \multirow{3}{*}{1} & Regression & 2171,752 & 2 & 225,809 &, $000^{\mathrm{b}}$ \\
\hline & Residual & 399,132 & 83 & & \\
\hline & Total & 2570,884 & 85 & & \\
\hline
\end{tabular}


Hasil pengujian diatas menunjukkan nilai F-hitung sebesar 225.889 dengan niliai signifikani $0,000^{\mathrm{b}}$. Artinya secara keseluruhan model telah signifikan.

Setelah diketahui bahwa model regresi yang dihasilkan telah signifikan maka langkah selanjutnya adalah melakukan pengujian secara parsial dari masingmasing variabel dalam model. Untuk keperluan ini dilakukan pengujian dengan menggunakan uji parsial dengan menggunakan nilai t-hitung. Berdasarkan output sebelumnya diperoleh nilai t-hitung untuk variable Penerapan Sistem EFilling adalah sebesar 5.730, variabel pemahaman internet sebesar 5.590 dengan nilai signifikansi 0,000. Dengan demikian dapat disimpulkan bahwa hipotesis diterima, atau kedua variabel tersebut mempunyai pengaruh yang signifikan terhadap Kepatuhan Wajib Pajak. Adapun variabel interaksi antara penerapan E-feeling dan pemahaman internet memiliki nilai t-hitung yang lebih besar dari t-tabel sehingga Ha diterima. Dengan kata lain pemahaman internet mempengaruhi interaksi antara penerapan E-Feeling dengan Kepatuhan Wajib Pajak dan pengaruhnya

Berdasarkan analisis data yang dilakukan oleh peneliti hal ini menunjukkan bahwa terdapat pengaruh antara Penerapan Sistem E-Filling terhadap Kepatuhan Wajib Pajak. Pajak merupakan sumber utama penerimaan negara yang dikelola oleh Direktorat Jenderal Pajak. Untuk dapat memaksimalkan sumber penerimaan negara, dibutuhkan Wajib Pajak yang patuh melaksanakan kewajibannya yaitu membayarkan pajaknya kepada negara. Maka dari itu, Direktorat Jenderal Pajak selalu berupaya mengoptimalkan pelayanannya supaya Wajib Pajak tidak enggan melaksanakan kewajibannya. Salah satu cara mengoptimalkan pelayanan tersebut adalah dengan memperbarui atau menyempurnakan sistem administrasi perpajakan atau biasa dikenal dengan istilah sistem administrasi perpajakan modern yang dilakukan melalui reformasi administrasi perpajakan yang diharapkan dapat memberikan kemudahan dan kenyamanan dalam pelayanannya kepada Wajib Pajak untuk memenuhi kewajiban perpajakannya (Gunadi Yuniar Rachdianti. (2011). E-filling merupakan bagian dari reformasi administrasi perpajakan yang bertujuan untuk memudahkan dalam pembuatan dan penyerahan laporan SPT kepada Direktoran Jenderal Pajak. Dengan diterapan sistem e-filling diharapkan dapat memberikan kenyaman dan kepuasan kepada Wajib Pajak sehingga dapat meningkatkan kepatuhan Wajib Pajak (Ayu, 2005).

Hasil penelitian ini mendukung penelitian sebelumnya yang dilakukan oleh Ernawati, Anni (2011) dengan judul Pengaruh Teknologi Informasi (e-sistem) terhadap kepatuhan wajib pajak (studi kasus dikantor pelayanan pajak pratama mojokerto) yang hasilnya membuktikan variabel-variabel e-sistem yaitu E-REG, E-SPT, E-Filling dan E-NPWP tidak berpengaruh signifikan secara statistik terhadap kepatuhan waib pajak di KPP Pratama mojokerto dan hasil uji statistik menunjukan bahwa $E-R E G$ merupakan variabel yang mpunyai nilai koefisien yang tebesar dibandingkan variabel lainya. Dalam penelitian juga ini ditemukan bahwa masih banyak wajib pajak yang belum begitu memahami manfaat e-sistem.

Selain itu, berdasarkan hasil pengujian hipotesis didapatkan hasil bahwa Pemahaman Internet memoderasi pengaruh antara Penerapan Sistem E-Filling terhadap Kepatuhan Wajib Pajak Rumah Sakit Umum Daerah Kabupaten Jombang yang dilihat dari nilai $-\mathrm{t}$ dengan nilai signifikansi 0,000. E-Filing merupakan program modernisasi yang dirancang untuk memanfaatkan teknologi 
secara maksimal. Menurut PER-01/PJ/2014, e-Filing adalah suatu cara penyampaian SPT Tahunan secara elektronik yang dilakukan secara online dan real time melalui internet pada website Direktorat Jenderal Pajak (www.pajak.go.id) atau Penyedia Jasa Aplikasi atau Applicatiom Service Provider (ASP).

Sistem e-filling merupakan layanan pengisian dan penyampaian Surat Pemberitahuan Wajib Pajak secara elektronik kepada Direktorat Jenderal Pajak yang bertujuan untuk memberikan kenyamanan dan kemudahan bagi Wajib Pajak dalam penyampaian Surat Pemberitahuannya dengan memanfaatkan jaringan komunikasi internet. Untuk dapat menggunakan system tersebut, Wajib Pajak dituntut untuk mengerti atau paham terhadap internet yaitu mengetahui bagaimana cara mengoperasikan internet. Apabila Wajib Pajak tidak dapat mengoperasikan internet, penerapan sistem tersebut tidak berpengaruh apa-apa terhadap kenyaman dan kemudahan dalam penyampaian SPT kepada kantor pajak yang diharapkan dapat meningkatkan kepatuhan Wajib Pajak (Utomo, 2015)

Hasil penelitian ini sesuai dengan penelitian Berly Angkoso. (2010). dengan judul Analisis Perilaku Wajib Pajak terhadap Penerapan Sistem E-Filling Direktorat Jenderal Pajak hasil penelitian menunjukkan bahwa faktor-faktor yang mempengaruhi perilaku penerimaan Wajib Pajak terhadap E-Filling adalah persepsi kegunaan, persepsi kemudahan penggunaan, sikap terhadap penggunaan, kesukarelaan menggunakan dan norma subyketif. Mayoritas responden dalam penelitian tersebut menyatakan bahwa E-Filling dapat diterima sebagai sistem pelaporan pajak secara online dan realtime.

\section{E. PENUTUP}

Berdasarkan hasil penelitian dapat disimpulkan bahwa: Sistem E-Filling berpengaruh terhadap Kepatuhan Wajib Pajak di Rumah Sakit Umum Daerah Kabupaten Jombang dan juga pemahaman internet memoderasi pengaruh Penerapan Sistem E-Filling terhadap Kepatuhan Wajib Pajak di Rumah Sakit Umum Daerah Kabupaten Jombang. Berdasarkan kesimpulan di atas maka beberapa saran dapat dikemukakan sebagai berikut: 1) Direktorat Jenderal Pajak diharapkan mensosialisasikan tata cara penggunaan e-filing lewat iklan di kantor pajak terutama untuk pemula. 2) Direktorat Jenderal Pajak sebaiknya lebih menyederhanakan sistem e filing karena banyak Wajib Pajak yang merasa kesuliatan dalam menggunakan e-filing.

\section{DAFTAR PUSTAKA}

Berly Angkoso. (2010). "Pengaruh Reformasi Administrasi Perpajakan, Pengetahuan Dasar Wajib Pajak tentang Perpajakan, dan Kesadaran Perpajakan terhadap Kepatuhan Wajib Pajak”. Skripsi. Fakultas Ekonomi dan Bisnis Universitas Islam Negeri Syarif Hidayatullah.

Diana Sari. (2013). Konsep Dasar Perpajakan. Bandung : PT.Refika Aditama. 
Feri Kristianto. (2014). Fuad Rahmany : Tingkat Kepatuhan Wajib Pajak Masih Jurnal akuntansi.

Ghozali I (2011). Analisis Multivariat dengan menggunakan SPSS. Edisi Tiga. Semarang. Badan Penerbit Universitas Diponegoro

Keputusan Direktur Jenderal Pajak Nomor Kep-88/PJ/2004 tentang Penyampaian Surat Pemberitahuan Secara Elektronik.

Mutiarni, R. (2017). Implementasi Electronic Data Processing Pada Koperasi Wanita. Eksis: Jurnal Riset Ekonomi dan Bisnis, $12(2$ Okt), 135148.Novarina Ayu Ika . (2005). "Implementasi Electronic Filling System (E-Filling) dalam Praktik Penyampaian Surat Pemberitahuan (SPT) di Indonesia”. Tesis. Program Studi Pasca Sarjana Magister Kenotariatan. Universitas Diponegoro Semarang.

Peraturan Menteri Keuangan Nomor 192/PMK.03/2007 tentang Tata Cara Penetapan Wajib Pajak dengan Kriteria Tertentu dalam Rangka

Pengembalian Pendahuluan Kelebihan Pembayaran Pajak. Undang-Undang No. 16 tahun 2009 tentang Ketentuan Umum dan Tata Cara Perpajakan.

Sari Nurhidayah. (2015). "Pengaruh Penerapan Sistem E-Filling Terhadap Kepatuhan Wajib Pajak Dengan Pemahaman Internet Sebagai Variabel Pemoderasi Pada Kpp Pratama Klaten”. Skripsi. Program Studi Akuntansi Universitas Negeri Yogyakarta.

Yuniar Rachdianti. (2011). "Hubungan antara Self-Control dengan Intensitas Penggunan Internet Remaja Akhir". Skripsi. Fakultas Psikologi non-Reguler Universitas Islam Negeri Syarif Hidayatullah. Jakarta.

Utomo, L. P. (2015). Pengaruh Postur Motivasi Atas Cara Pandang Wajib Pajak Kepada Fiskus Terhadap Kepatuhan Pembayaran Pajak Orang Pribadi. Eksis: Jurnal Riset Ekonomi dan Bisnis, 10(2 Okt). 